\title{
Effect of Enteral Versus Parenteral Feeding on Leucine Kinetics and Fuel Utilization in Premature Newborns
}

\author{
SCOTT C. DENNE, CHERYL A. KARN, YA MEI LIU, CATHERINE A. LEITCH, AND \\ EDWARD A. LIECHTY \\ Department of Pediatrics, Section of Neonatal-Perinatal Medicine, Indiana University School of \\ Medicine, Indianapolis, Indiana 46202-5210
}

\section{ABSTRACT}

\begin{abstract}
To determine whether the route of nutrient delivery affects whole-body protein kinetics and fuel utilization, eight premature newborns were studied during both a 4-h period of enteral intake and a 4-h period of parenteral nutrition. The kinetics of the essential amino acid leucine were measured using a constant tracer infusion of $1-{ }^{13} \mathrm{C}$ leucine, and fuel utilization and energy expenditure were assessed by respiratory calorimetry. All leucine kinetic parameters were similar during enteral or parenteral nutrition (in mean $\pm \mathrm{SD} \mu \mathrm{mol} / \mathrm{kg} / \mathrm{h}$, flux $=233 \pm 51$ enteral versus $258 \pm 42$ parenteral, leucine from protein breakdown $=177 \pm 50$ enteral versus $200 \pm 41$ parenteral, leucine oxidation $=57 \pm 26$ enteral versus $63 \pm 20$ parenteral, and leucine used for protein synthesis $=176 \pm 63$ enteral versus $196 \pm 50$ parenteral). In addition, overall
\end{abstract}

Parenteral feeding is used extensively in the clinical care of premature newborns. It is often used before beginning enteral nutrition as well as during times when a change in clinical status necessitates interrupting enteral feedings. In addition, parenteral nutrition is used to supplement the early stages of enteral feeding, when total nutritional requirements are not met by enteral feedings alone. Parenteral feeding is thus widely regarded as an appropriate substitute for enteral intake in premature newborns, at least for brief periods of time. However, it is unclear whether the metabolic effects of short-term parenteral nutrition mirror those of enteral feeding in premature infants. For example, it is not certain whether carbohydrate and fat are similarly utilized for oxidative metabolism if given by the parenteral or enteral route. It is also unclear whether overall protein metabolism is

Received March 9, 1993; accepted April 10, 1994.

Correspondence and reprint requests: Scott C. Denne, M.D., Indiana University School of Medicine, 702 Barnhill Dr., RR208, Indianapolis, IN 46202-5210.

Supported in part by National Institutes of Health Grants M01 RR750, P60 DK20542, K08 HD 00840, R01 HD 29153, and S10 RR 07269, by the James Whitcomb Riley Memorial Association, and by Bristol-Meyers Squibb. rates of energy expenditure $(\sim 52 \mathrm{kcal} / \mathrm{kg} / \mathrm{d})$ and pattern of fuel utilization ( $\sim 70 \%$ carbohydrate, $13 \%$ fat, $17 \%$ protein) were unaltered by the route of feeding. Thus, as reflected by leucine kinetics, overall rates of protein turnover, synthesis, oxidation, and breakdown as well as energy expenditure and fuel utilization are similar when nutrition is provided to premature newborns by either the enteral or parenteral route. These results suggest that short-term provision of parenteral nutrition may be able to substitute appropriately for enteral intake, at least with regard to the utilization of one essential amino acid and the overall pattern of fuel utilization. (Pediatr Res 36: 429-435, 1994)

KIC, $\alpha$-ketoisocaproic acid

differently affected by the parenteral administration of nutrients. Previous studies carried out in both premature infants and adults demonstrated significant reductions in protein turnover during parenteral compared with enteral feeding (1-3). However, in these studies, protein kinetic measurements were made during parenteral nutrition after a prolonged period in which enteral feeding was withheld, thus raising the possibility that the observed differences in protein kinetics resulted from an adaptation to the unused gastrointestinal tract (1-3). Alternatively, lower rates of protein turnover may be a direct effect of parenteral substrate. Because of the widespread clinical use of parenteral nutrition to supplement or substitute for enteral feeding, it is of practical importance to assess whether parenteral feeding directly alters protein kinetics, as well as to determine whether this route of substrate administration alters macronutrient oxidation.

To address these issues, we studied premature infants during both a 4-h period of enteral intake and a 4-h period of parenteral nutrition. The kinetics of the essential amino acid leucine (as a reflection of overall protein kinetics) were measured using a constant tracer infusion 
of $1-{ }^{13} \mathrm{C}$-leucine, and fuel utilization and energy expenditure were assessed by respiratory calorimetry. All infants were enterally fed before study, so prolonged disuse of the gastrointestinal tract was eliminated as a possible complicating factor. Thus, any alterations in protein kinetics or substrate oxidation would be a direct consequence of the acute change in the route of nutrient administration.

\section{METHODS}

Subjects. The patients eligible for this study were premature infants between 30 and $35 \mathrm{wk}$ gestational age who were at or approaching a full feeding schedule and were less than $14 \mathrm{~d}$ old. Excluded from the study were infants who had congenital anomalies, required supplemental oxygen, or had undergone surgery. The eight premature infants studied had a birth weight of $1.83 \pm 0.37 \mathrm{~kg}$ (mean $\pm \mathrm{SD}$ ), a gestational age of $32.1 \pm 1.7 \mathrm{wk}$, and a weight of $1.76 \pm 0.37 \mathrm{~kg}$ when studied at $7.0 \pm 3.1 \mathrm{~d}$ of age. All infants received both $4 \mathrm{~h}$ of enteral feeding and $4 \mathrm{~h}$ of parenteral feeding during the study. The order of feeding was randomized (enteral-parenteral, $n=4$; parenteralenteral, $n=4)$.

Study protocol. Three h after the infants' regular feeding, either hourly enteral or continuous parenteral feeding was initiated. After an approximately 1.5 -h equilibration period, a baseline blood sample was obtained from a 22 -gauge catheter placed in a superficial arm vein. This catheter was used to draw all subsequent blood samples during the study, and patency was maintained by a normal saline infusion $(2 \mathrm{~mL} / \mathrm{h})$. A primed $(5 \mu \mathrm{mol} / \mathrm{kg})$ constant infusion $(6 \mu \mathrm{mol} / \mathrm{kg} / \mathrm{h})$ of $1-{ }^{13} \mathrm{C}$-leucine $(99 \%$ atom $\%$ excess; Merck Sharpe \& Dohme, Quebec, Canada) dissolved in sterile saline was then begun through a second (24-gauge) catheter placed in the opposite extremity. The tracer infusion was delivered at a constant rate by a Harvard infusion pump (Harvard Apparatus, Inc., South Natick, MA). Blood samples were obtained at 210, 225, and $240 \mathrm{~min}$. After drawing the 240 -min sample, the mode of feeding was changed and continued for an additional 4 h. Blood samples were again obtained at 450,465 , and $480 \mathrm{~min}$. The total amount of blood taken for the study was $6.0 \pm 0.8 \mathrm{~mL}$.

Resting oxygen consumption and carbon dioxide production were measured using open circuit respiratory calorimetry as previously described (4). The system was calibrated by combustion of absolute ethyl alcohol and the results were within $5 \%$ of expected values. Respiratory calorimetry was performed for $\geq 20 \mathrm{~min}$ at hourly intervals throughout the entire study. Subjects were quiet or sleeping for all measurements.

For the enteral feeding portion of the study, hourly feedings of Enfamil premature formula (Mead Johnson, Evansville, IN) calculated to provide $3.3 \mathrm{~mL} / \mathrm{kg} / \mathrm{h}$ were used. This rate of feeding corresponds to $2 \mathrm{~g} / \mathrm{kg} / \mathrm{d}$ of protein, $3.4 \mathrm{~g} / \mathrm{kg} / \mathrm{d}$ of fat, and $7.3 \mathrm{~g} / \mathrm{kg} / \mathrm{d}$ of carbohydrate. The actual enteral intake was quantified by weighing the bottle before and after each hourly feeding. For the parenteral nutrition portion of the study, an i.v. solution containing amino acids (FreAmineIII, Kendall McGaw Laboratories, Inc., Irvine, CA), lipid (Intralipid, KabiVitrum, Alameda, CA), and glucose $(10 \%)$ was delivered at a rate of $3.3 \mathrm{~mL} / \mathrm{kg} / \mathrm{h}$. The solution was made to approximate the substrate intake of the enteral feeding. The caloric contribution of carbohydrate was $44 \%$, fat $46 \%$, and protein $12 \%$ in both the enteral and parenteral solutions.

Actual protein, leucine, carbohydrate, fat, and total caloric intakes are shown in Table 1. Although the intended delivery of nutrients was $3.3 \mathrm{~mL} / \mathrm{kg} / \mathrm{h}$, the actual delivery rate of parenteral nutrition was slightly higher and that of enteral feedings slightly lower (determined by bottle weight) than the target rate. Thus, the intake of protein, carbohydrate, and fat was slightly $(\sim 8 \%)$ but statistically higher $(>0.05)$ during parenteral feeding. Leucine intake, however, was not different between the two groups $(p=0.31)$.

The protocol was approved by the Indiana University Institutional Review Board and written informed consent was obtained from the infants' parents after the procedures were fully explained to them.

Analytical procedures. The ${ }^{13} \mathrm{C}$ enrichment of plasma leucine was determined by chemical ionization on a Hewlett-Packard 5988 gas chromatograph mass spectrometer (Hewlett-Packard Co., Palo Alto, CA) after derivitization to the $\mathrm{N}$-acetyl n-propyl ester as previously described (5). The plasma enrichment of KIC was determined by electron impact ionization on a Hewlett-Packard 5970 gas chromatograph mass spectrometer after derivitization to the o-trimethylsiloquinoxalinol (6).

The ${ }^{13} \mathrm{C}$ enrichment of carbon dioxide in blood bicarbonate was measured after separation of the carbon dioxide by cryogenic distillation in vacuum as previously described (6). Combustion analysis was performed to assess whether the natural abundance of ${ }^{13} \mathrm{C}$ differed between the enteral and parenteral nutrient mixtures. Aliquots of both the parenteral mixture (triple mix) and the formula used in four of the studies were combusted using a modified version of the method used by Craig (7). Specifically, 2-mL samples of parenteral solution or formula were placed in 12-inch previously annealed Pyrex tubes containing $500 \mathrm{mg}$ of $\mathrm{CuO}$ and a $2.5-\mathrm{cm}$ length of $\mathrm{Ag}$ wire. Tubes were frozen in liquid nitrogen, vacuated, sealed, and heated at $500^{\circ} \mathrm{C}$ for $4 \mathrm{~h}$. The carbon dioxide was subsequently cryogenically purified and analyzed by mass spectrometry (model 252, Finnigan MAT, San Jose,

Table 1. Substrate intake during enteral and parenteral feeding

\begin{tabular}{lcc}
\hline & Enteral & Parenteral \\
\hline Total intake $(\mathrm{mL} / \mathrm{kg} / \mathrm{h})$ & $3.18 \pm 0.27$ & $3.36 \pm 0.08$ \\
Carbohydrate $(\mathrm{mg} / \mathrm{kg} / \mathrm{h})$ & $283 \pm 24$ & $307 \pm 8$ \\
Fat $(\mathrm{mg} / \mathrm{kg} / \mathrm{h})$ & $131 \pm 11$ & $143 \pm 4$ \\
Protein $(\mathrm{mg} / \mathrm{kg} / \mathrm{h})$ & $76 \pm 6$ & $84 \pm 2$ \\
Leucine $(\mu \mathrm{mol} / \mathrm{kg} / \mathrm{h})$ & $56 \pm 5$ & $58 \pm 2$ \\
Calories $(\mathrm{kcal} / \mathrm{kg} / \mathrm{h})$ & $2.58 \pm 0.22$ & $2.81 \pm 0.07$ \\
\hline
\end{tabular}


CA). Each sample of parenteral solution or formula was analyzed in triplicate. There was no difference between the background ${ }^{13} \mathrm{C}$ abundance in parenteral versus enteral nutrient solutions (parenteral $-21.97 \pm 1.34 \delta$ versus enteral $-21.39 \pm 0.26 \delta, p=0.5$ ).

Amino acid concentrations were measured on a Beckman 6300 amino acid analyzer (Beckman Instruments, Inc., Palo Alto, CA). Plasma glucose concentrations were measured by the glucose oxidase method using a Yellow Springs glucose analyzer (Yellow Springs Instrument Co., Yellow Springs, $\mathrm{OH}$ ). Plasma insulin concentrations were measured by double antibody RIA.

Calculations. Whole-body leucine kinetics were calculated from the plasma enrichment of leucine and the ${ }^{13} \mathrm{CO}_{2}$ excretion rate as previously described $(8,9)$. The recovery of ${ }^{13} \mathrm{CO}_{2}$ was assumed to be $80 \%(10,11)$. In addition, an alternative estimation of leucine kinetics was calculated in the same way using steady state plasma enrichment of KIC. Whole-body rates of protein metabolism were calculated from leucine kinetics (plasma enrichment of leucine) by assuming the leucine content of $590 \mu \mathrm{mol} / \mathrm{g}$ of protein (12).

As in analogous studies in human adults (13), we assumed that all of the enteral leucine provided was completely absorbed. The net protein digestibility in premature newborns has been determined at approximately $90 \%$ (14); however, measurements using balance technique include protein losses that are not necessarily from unabsorbed dietary protein (i.e. protein from loss of intestinal mucosa and secretions is included). On the other hand, when dietary absorption is assessed using labeled leucine or protein hydrolyzates, absorption is 98-99\% (15). Thus, the true rate of leucine absorption from protein is likely to lie between 90 and $98 \%$.

We also assumed that dietary leucine would no longer be contributing to leucine kinetics by the fourth hour of parenteral infusion. To the extent this assumption was not true, there should have been a difference between the group of infants who were fed enterally first and those who were fed parenterally first; there was no such difference between these two groups.

Oxygen consumption, carbon dioxide production, and energy expenditure were calculated as previously described (16). Substrate oxidation was calculated from RQ measurements and protein oxidation (derived from leucine oxidation) $(4,17,18)$.

Statistics. All values are expressed as mean \pm SD. A one-way analysis of variance was used to test for an effect of feeding order for each of the measured parameters. Finding no order effect, comparisons of enteral and parenteral feeding were made using a paired $t$ test.

\section{RESULTS}

Substrate and hormone concentrations. Plasma glucose concentrations achieved steady state during both feeding periods (coefficient of variation at plateau $=6 \%$ ). Glucose concentrations were unaltered by the route of feed- ing $(4.2 \pm 0.4 \mu \mathrm{mol} / \mathrm{L}$ enteral, $4.3 \pm 0.6 \mu \mathrm{mol} / \mathrm{L}$ parenteral). Insulin concentrations were also similar during enteral and parenteral feeding $(23 \pm 10 \mathrm{pmol} / \mathrm{L}$ enteral versus $24 \pm 21 \mathrm{pmol} / \mathrm{L}$ parenteral). In contrast, the concentrations of many individual amino acids (including most of the essential amino acids) were significantly greater during parenteral feeding (Table 2).

Leucine and protein kinetics. Steady state enrichments of leucine, $\mathrm{KIC}$, and ${ }^{13} \mathrm{CO}_{2}$ were achieved during both the enteral and parenteral periods, as demonstrated in Figure 1 . The coefficients of variation at plateau were $5 \%$ for leucine enrichment, $10 \%$ for KIC enrichment, and $11 \%$ for ${ }^{13} \mathrm{CO}_{2}$ enrichment. The ratio of KIC to leucine was unaffected by the mode of feeding $(0.75 \pm 0.19$ enteral versus $0.73 \pm 0.13$ parenteral) and is similar to the ratio of $\mathrm{KIC}$ to leucine reported in adults (19). Table 3 shows leucine kinetics calculated on the basis of both leucine enrichment and KIC enrichment during enteral and parenteral feeding. There were no differences between the two feeding modes in leucine flux, oxidation, nonoxidative disposal (a reflection of protein synthesis), or leucine from protein breakdown, no matter which precursor was used in the calculation. The leucine kinetic values measured in the present study during enteral feeding are similar to those obtained in previous studies of premature infants during enteral feeding by ourselves and others $(9,20)$. Leucine balance (leucine intake - leucine oxidation) was not different between enteral and parenteral feeding using either leucine or KIC enrichment as the precursor. Leucine balance was near zero when based on the leucine enrichment (enteral, $-1 \pm 29 \mu \mathrm{mol} / \mathrm{kg} / \mathrm{h}$; parenteral, $-4 \pm 19 \mu \mathrm{mol} / \mathrm{kg} / \mathrm{h}$ ) and was negative when based on the KIC enrichment (enteral, $-22 \pm 37 \mu \mathrm{mol} /$ $\mathrm{kg} / \mathrm{h}$; parenteral, $-31 \pm 33 \mu \mathrm{mol} / \mathrm{kg} / \mathrm{h}$ ). Whole-body rates of protein turnover, breakdown, oxidation, and synthesis calculated from leucine kinetic values (leucine enrichment) are shown in Figure 2.

Table 2. Plasma amino acid concentrations during enteral and parenteral feeding*

\begin{tabular}{lccc}
\hline & $\begin{array}{c}\text { Enteral } \\
(\mu \mathrm{mol} / \mathrm{L})\end{array}$ & $\begin{array}{c}\text { Parenteral } \\
(\mu \mathrm{mol} / \mathrm{L})\end{array}$ & $p$ \\
\hline Threonine & $396 \pm 192$ & $431 \pm 194$ & $<0.05$ \\
Serine & $241 \pm 59$ & $294 \pm 48$ & $<0.001$ \\
Glutamine & $1183 \pm 404$ & $1222 \pm 334$ & $\mathrm{NS}$ \\
Proline & $180 \pm 102$ & $1141 \pm 777$ & $\mathrm{NS}$ \\
Glycine & $412 \pm 51$ & $647 \pm 101$ & $<0.001$ \\
Alanine & $209 \pm 63$ & $343 \pm 43$ & $<0.05$ \\
Valine & $174 \pm 22$ & $222 \pm 35$ & $<0.01$ \\
Cysteine & $11 \pm 5$ & $11 \pm 4$ & $\mathrm{NS}$ \\
Methionine & $65 \pm 14$ & $114 \pm 21$ & $<0.001$ \\
Isoleucine & $46 \pm 7$ & $82 \pm 21$ & $<0.01$ \\
Leucine & $109 \pm 13$ & $143 \pm 25$ & $<0.01$ \\
Tyrosine & $204 \pm 118$ & $177 \pm 105$ & $\mathrm{NS}$ \\
Phenylalanine & $73 \pm 15$ & $99 \pm 24$ & $<0.01$ \\
Tryptophan & $112 \pm 18$ & $114 \pm 9$ & $\mathrm{NS}$ \\
Lysine & $172 \pm 39$ & $208 \pm 49$ & $<0.01$ \\
Arginine & $104 \pm 47$ & $156 \pm 57$ & $<0.01$ \\
\hline
\end{tabular}

* Values are mean \pm SD. 

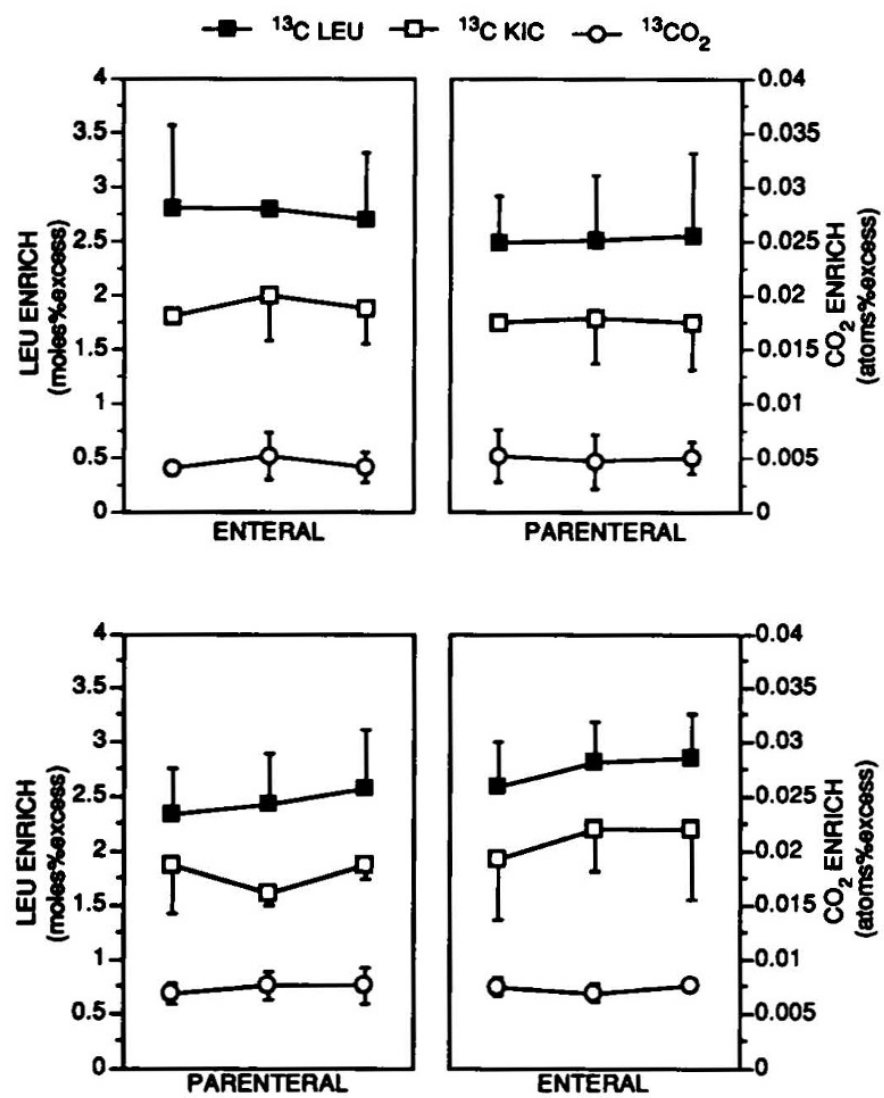

Figure 1. Isotopic enrichments of leucine $(L E U), \mathrm{KIC}$, and carbon dioxide during enteral and parenteral feeding. The top two panels are the enrichments measured in the four premature infants who received enteral feeding first; the bottom two panels are enrichments measured in the four premature infants who received parenteral feeding first.

Energy expenditure and fuel utilization. Oxygen consumption, carbon dioxide production, $R Q$, and energy expenditure are shown in Figure 3. No difference between any of these parameters was detected between the two feeding modes. These values were similar to those found in previous studies of premature infants receiving both enteral and parenteral nutrition (21-23).

The nonprotein $\mathrm{RQ}$ was unchanged by the mode of feeding $(0.956 \pm 0.066$ enteral versus $0.949 \pm 0.074$ parenteral). Absolute carbohydrate oxidation rates calculated from the nonprotein quotient were also similar between the two feeding modes $(7.1 \pm 2.4 \mathrm{mg} / \mathrm{kg} / \mathrm{min}$ enteral versus $6.2 \pm 1.6 \mathrm{mg} / \mathrm{kg} / \mathrm{min}$ parenteral). These carbohydrate oxidation rates were within the range of those previously reported in premature newborns (23).

Table 3. Leucine kinetics during enteral and parenteral feeding*

\begin{tabular}{lccccc}
\hline & \multicolumn{2}{c}{ Leucine enrichment } & & \multicolumn{2}{c}{ KIC enrichment } \\
\cline { 2 - 3 } \cline { 5 - 6 } & Enteral & Parenteral & & Enteral & Parenteral \\
\hline Flux & $233 \pm 51$ & $258 \pm 42$ & & $320 \pm 71$ & $367 \pm 87$ \\
Oxidation & $57 \pm 26$ & $63 \pm 20$ & & $78 \pm 34$ & $89 \pm 34$ \\
Intake & $56 \pm 5$ & $58 \pm 2$ & & $56 \pm 5$ & $58 \pm 2$ \\
Nonoxidative disposal & $176 \pm 63$ & $196 \pm 50$ & & $241 \pm 85$ & $278 \pm 82$ \\
From protein breakdown & $177 \pm 50$ & $200 \pm 41$ & & $264 \pm 69$ & $309 \pm 87$ \\
\hline
\end{tabular}

* All values are in $\mu \mathrm{mol} / \mathrm{kg} / \mathrm{h}$.

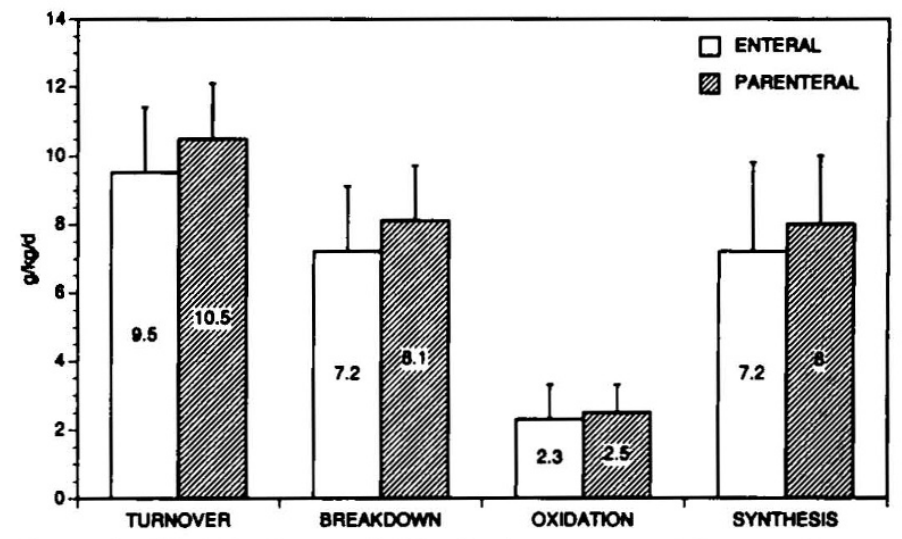

Figure 2. Whole-body protein kinetics in premature infants during enteral and parenteral feeding.

The pattern of fuel utilization calculated from the RQ and leucine oxidation is shown in Figure 4. As expected, carbohydrate contributed the greatest proportion to oxidative metabolism during both enteral and parenteral feeding. The overall contribution of carbohydrate, fat, or protein to oxidative metabolism was unaffected by mode of feeding in these premature infants.

\section{DISCUSSION}

The present study demonstrates that providing nutrition enterally or parenterally to premature infants does not result in differences in the kinetics of the essential amino acid leucine. As reflected by leucine kinetics, rates of whole-body protein turnover, synthesis, breakdown, and oxidation are independent of the route of feeding. Furthermore, measurements of energy expenditure and fuel utilization are similar during parenteral and enteral nutrition.

As in all studies of protein kinetics, the design and overall model must be carefully considered. We performed a paired study to maximize the likelihood of finding differences between feeding modes and to control for the effect of gestational and postnatal age. In addition, we used a crossover design to control for any order effect. This design minimizes the potential confounding effect of isotope recycling, for example. It is important to point out that in the present study no order effect was detected for any of the measured parameters. Finally, we determined leucine kinetics based on the enrichments of both leucine and KIC. The enrichment of KIC may better represent intracellular leucine enrichment (24) and thus more accurately reflect whole-body fluxes. The fact that leucine kinetics are similar during enteral and parenteral feeding regardless of the precursor used for calculation adds credibility to the findings.

Despite the design strengths of the current study, we must also acknowledge its limitations. The modest caloric and protein intakes used in the present study approximated maintenance requirements but were inadequate for growth. We chose these intakes because they are typical among 7-d-old premature infants fed by either 

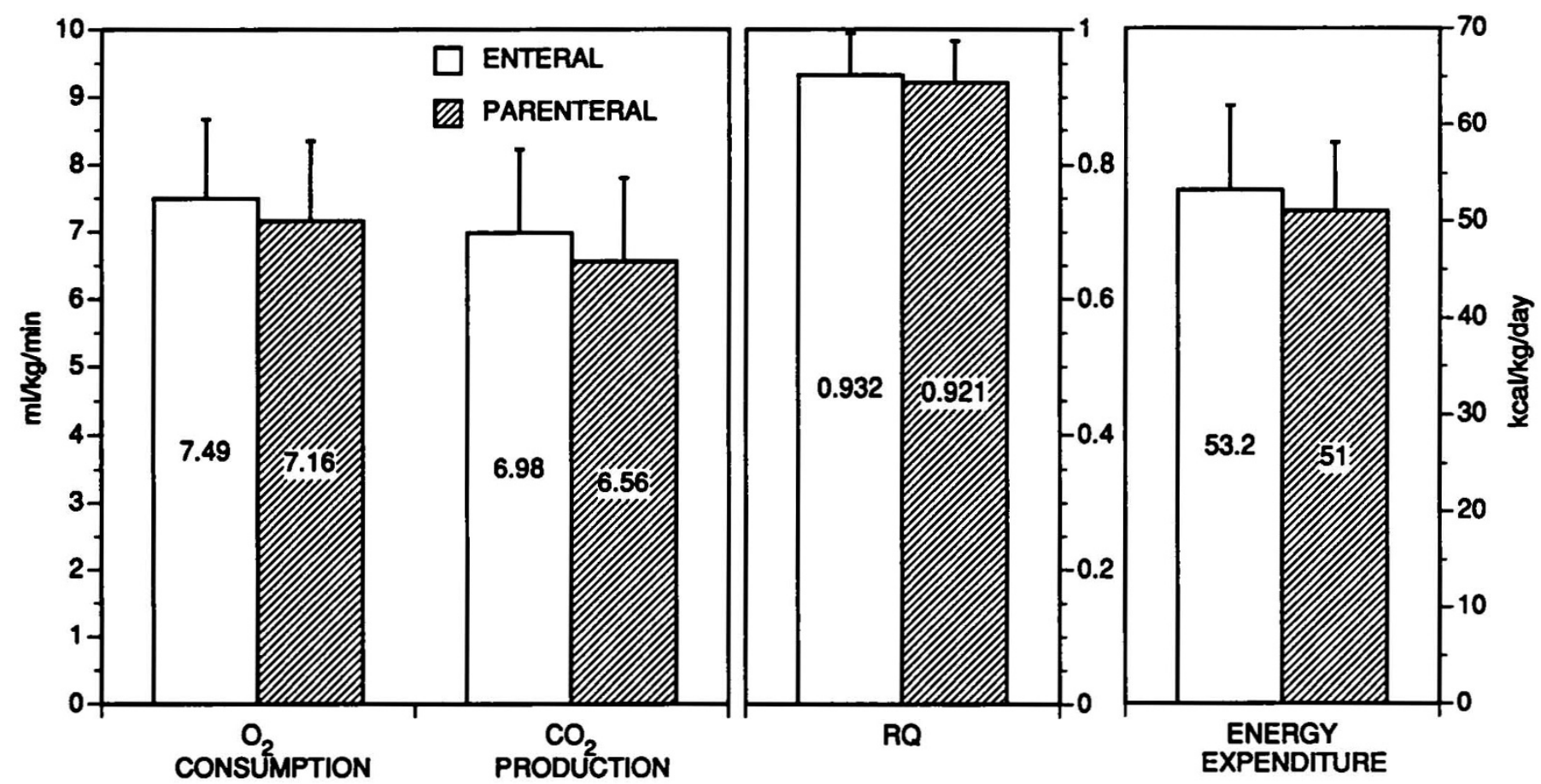

Figure 3. Oxygen consumption, carbon dioxide production, RQ, and overall energy expenditure in premature infants during enteral and parenteral feeding.

the enteral or the parenteral route. It is conceivable that different results would be obtained using higher caloric and protein intakes or with alternative (i.e. specialized neonatal) amino acid solutions.

We also must point out that, although leucine intakes during enteral and parenteral nutrition were virtually identical, caloric intake during parenteral nutrition was approximately $0.2 \mathrm{kcal} / \mathrm{kg} / \mathrm{h}$ higher than during enteral intake. It seems unlikely that this marginal difference in caloric intake would substantially influence the results, especially with regard to leucine from protein breakdown (25). However, this possible influence cannot be completely excluded.

Probably the most important consideration regarding the leucine model used in the present study is assessing the effect of splanchnic extraction of enteral leucine. It is

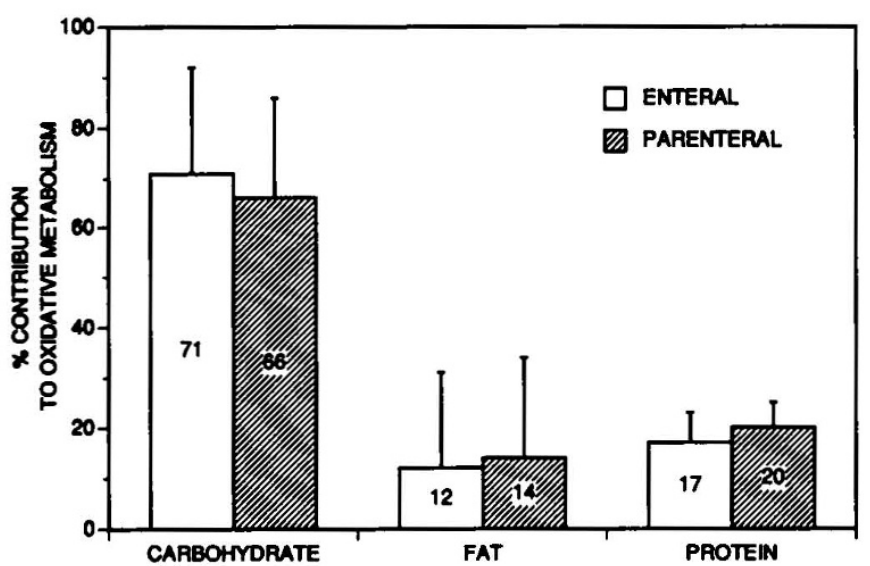

Figure 4. Pattern of fuel utilization in premature infants during enteral and parenteral feeding. clear that some percentage of the leucine provided by enteral feedings is taken up by splanchnic tissues and does not appear in the systemic circulation (26). Splanchnic extraction thus results in an underestimation of total leucine flux, oxidation, leucine used for protein synthesis, and leucine released from endogenous protein. In studies carried out in adults, approximately $25 \%$ of enteral leucine was extracted by the splanchnic organs $(19$, 26). However, in a recent study performed in premature infants, splanchnic extraction of leucine was found to be considerably higher (48\%) (27). It is possible to estimate the effect of splanchnic extraction in the present study by assuming that 1) $48 \%$ of enteral leucine intake does not appear in the systemic circulation and 2) $14 \%$ of enteral leucine intake is oxidized on the first pass [as determined in adults in the fed state by Beaufrere et al. (28) and calculated by Matthews et al. (29)]. Applying these corrections to the present data set results in leucine kinetic measurements that are virtually identical during enteral and parenteral feeding (in $\mu \mathrm{mol} / \mathrm{kg} / \mathrm{h}$, enteral versus parenteral: leucine flux, $263 \pm 52$ versus $258 \pm 42$; oxidation, $65 \pm 25$ versus $63 \pm 20$; leucine for protein synthesis, $198 \pm 64$ versus $196 \pm 50$; and leucine from protein breakdown, $204 \pm 51$ versus $200 \pm 41$ ). Although these estimates of splanchnic extraction may not be quantitatively precise, it is clear that accounting for splanchnic extraction will minimize rather than exaggerate any of the (nonsignificant) differences between enteral and parenteral feeding.

Previous studies in animals and humans have measured differences in whole-body protein kinetics depending on the route of nutrient administration. Duffy and 
Pencharz (1), using the ${ }^{15} \mathrm{~N}$-glycine method in postsurgical neonates, showed protein turnover, synthesis, and breakdown to be $40 \%$ lower during parenteral compared with enteral feeding. Jeevanandam (2) demonstrated similar reductions in protein kinetics in normal adults using the same technique. In a study examining proteindepleted rats, Maiz et al. (30) measured decreased rates of protein breakdown using a constant infusion of $1-{ }^{14} \mathrm{C}$ leucine during parenteral compared with enteral feeding. In each of these studies, the protein kinetic determinations during enteral feeding were made in subjects who received normal enteral feedings before study, whereas the protein kinetic measurements during parenteral nutrition were made after a prolonged period of no enteral intake. Thus, it was unclear whether the observed reductions in proteolysis were a direct effect of parenteral nutrition or a result of atrophic changes in the unused gastrointestinal tract $(3,31,32)$. It is the latter hypothesis that is supported by the present study; all infants were enterally fed up until the time of the study, and no differences in proteolysis were observed between the two feedings modes. Yu et al. (33) reported similar results in dogs. Enteral intake of a balanced amino acid mixture was compared with acute parenteral administration of the same amino acid solution; whole-body leucine kinetics were similar regardless of the route of administration. It is therefore likely that the reductions in proteolysis observed in previous investigations of parenteral feeding were significantly influenced by prolonged disuse of the gastrointestinal tract and the probable reduction in splanchnic protein turnover.

It must be noted that, although the metabolic fate of leucine at the whole-body level is similar during enteral and parenteral nutrition, specific organs may be affected differently depending on the route of feeding. Indeed, animal studies demonstrated a higher rate of leucine release from proteolysis in the gut as well as diminished net leucine balance in the gut and total splanchnic region during parenteral feeding (33). Although such measurements were not obtained in the present study, it is reasonable to suspect that parenteral nutrition may result in similar alterations in gut and splanchnic leucine metabolism in premature infants.

In the present study, concentrations of leucine (and other amino acids) were significantly higher during parenteral nutrition than during enteral feeding. This may reflect the effect of splanchnic extraction; alternatively, the differences in concentration may be a result of a brief alteration in leucine rate of appearance or rate of disappearance before a new steady state was established. In any case, despite these differences in leucine concentrations, no difference in leucine kinetics was measured. In particular, leucine oxidation was the same at two different leucine concentrations. Although some previous studies have found a positive relationship between leucine concentration and oxidation $(34,35)$, others have not $(13,36)$. Most pertinently, we have previously measured similar leucine oxidation rates in full-term newborns dur- ing feeding and fasting, despite different leucine concentrations in these two states $(8,16)$. It may be that in premature and term infants, leucine oxidation is much less sensitive to changes in leucine concentration.

These findings lead one to at least question the extensive use of plasma amino acid concentrations to reflect neonatal protein metabolism (37) and to design parenteral amino acid solutions $(38,39)$. Although maintaining plasma amino acid concentrations within some range is undoubtedly important, it seems apparent from the present study that amino acid concentrations do not necessarily reflect amino acid utilization. Thus, amino acid concentrations without kinetic data may be of limited significance in assessing overall neonatal protein metabolism.

In addition to leucine kinetics, we also assessed whether the route of nutrient administration affects energy expenditure and fuel utilization. Although the specific composition of carbohydrate, fat, and protein is substantially different in enteral formulas compared with parenteral solutions, it has been generally assumed that the route of administration does not alter the oxidative fates of these macronutrients. Nevertheless, this issue has not been specifically examined in premature newborns. As calculated from the RQ and leucine oxidation, the present study demonstrates that, despite differences in composition, the contribution of carbohydrate, fat, and protein to oxidative metabolism does not differ during parenteral and enteral nutrition. Overall energy expenditure is also similar during each of the two feeding modes.

In summary, the present study demonstrates that, compared with enteral feeding, the acute administration of parenteral nutrition to premature infants does not alter whole-body parameters of leucine metabolism (and by extrapolation, protein metabolism) or macronutrient oxidation. Because premature infants often receive parenteral nutrition for relatively brief periods of time, this finding may have clinical relevance. Short-term provision of parenteral nutrition appears to appropriately substitute for enteral intake, at least with regard to the whole-body utilization of one essential amino acid and the overall pattern of fuel utilization. However, additional studies will need to be performed in premature infants to assess the effect of parenteral nutrition on the utilization of other essential amino acids, as well as to determine how this route of nutrient administration affects protein metabolism in specific organs.

\section{REFERENCES}

1. Duffy B, Pencharz P 1986 The effect of feeding route (IV or oral) on the protein metabolism of the neonate. Am J Clin Nutr 43:108-111

2. Jeevanandam M 1987 Effect of the route of nutrient administration on whole body protein kinetics in man. Metabolism 36:968-973

3. Sim A, Wolfe B, Young V, Clarke D, Moore F 1979 Glucose promotes whole-body protein synthesis from infused amino acids in fasting man. Lancet 1:68-72

4. Denne S, Kalhan S 1986 Glucose carbon recycling and oxidation in human newborns. Am J Physiol 251:E71-E77

5. Mullen K, Denne S, McCullough A, Savin S, Bruno D, Tavill A, Kalhan S 1986 Leucine metabolism in stable cirrhosis. Hepatology $6: 622-630$ 
6. Ford GC, Cheng KN, Halliday D 1985 Analysis of $\left[1-{ }^{13} \mathrm{C}\right]$ leucine and $\left[{ }^{13} \mathrm{C}\right] \mathrm{KIC}$ in plasma by capillary gas chromatography/mass spectrometry in protein turnover studies. Biomed Environ Mass Spectrom 12:432-436

7. Craig H 1953 The geochemistry of the stable carbon isotopes. Geochim Cosmochim Acta 3:53-92

8. Denne S, Rossi E, Kalhan S 1991 Leucine kinetics during feeding in normal newborns. Pediatr Res 30:23-27

9. Denne SC, Karn CA, Liechty EA 1992 Leucine kinetics after a brief fast and in response to feeding in premature infants. Am J Clin Nutr 56:899-904

10. Allsop JR, Wolfe RR, Burke JF 1978 Tracer priming the bicarbonate pool. J Appl Physiol 45:137-139

11. Van Aerde JEF, Sauer PJJ, Pencharz PB, Canagarayar U, Beesley J, Smith JM, Swyer PR 1985 The effect of energy intake and expenditure on the recovery of ${ }^{13} \mathrm{CO}_{2}$ in the parenterally fed neonate during a 4-hour primed constant infusion of $\mathrm{HAH}{ }^{13} \mathrm{CO}_{2}$. Pediatr Res 19:806-810

12. Waterlow J 1984 Protein turnover with special reference to man. Q J Exp Physiol 69:409-438

13. Cortiella J, Matthews DE, Hoerr RA, Bier DM, Young VR 1988 Leucine kinetics at graded intakes in young men: quantitative fate of dietary leucine. Am J Clin Nutr 48:998-1009

14. Catzeflis C, Schutz Y, Micheli JL, Welsch MJ, Jequier E 1985 Whole body protein synthesis and energy expenditure in very low birth weight infants. Pediatr Res 19:679-687

15. Wutzke KD, Heine W, Plath C, Muller M, Uhlemann M 1992 Whole-body protein parameters in premature infants: a comparison of different ${ }^{15} \mathrm{~N}$ trace substances and different methods. Pediatr Res 31:95-101

16. Denne S, Kalhan S 1987 Leucine metabolism in human newborns. Am J Physiol 253:E608-E615

17. Denne S, Patel D, Kalhan S 1991 Leucine kinetics and fuel utilization during a brief fast in human pregnancy. Metabolism 40:1249-1256

18. Weir JBDV 1949 New methods for calculating metabolic rate with special reference to protein metabolism. J Physiol 109:1-9

19. Hoerr R, Matthews D, Bier D, Young V 1991 Leucine kinetics from $\left[{ }^{2} \mathrm{H}_{3}\right]$ and $\left[{ }^{13} \mathrm{C}\right]$ leucine infused simultaneously by gut and vein. Am $\mathrm{J}$ Physio 260:E111-E117

20. Beaufrère B, Putet G, Pachiaudi C, Salle B 1990 Whole body protein turnover measured with ${ }^{13} \mathrm{C}$-leucine and energy expenditure in preterm infants. Pediatr Res 28:147-152

21. Reichman B, Chessex P, Putet G, Verellen G, Smith JM, Heim T, Swyer PR 1981 Diet, fat accretion, and growth in premature infants. N Engl J Med 305:1495-1500

22. Gudinchet F, Schutz Y, Micheli J-L, Stettler E, Jequier E 1982 Metabolic cost of growth in very low birth weight infants. Pediatr Res 16:1025-1030

23. Lafeber H, Sulkers E, Chapman T, Sauer P 1990 Glucose production and oxidation in preterm infants during total parenteral nutrition. Pediatr Res 28:153-157
24. Schwenk WF, Beaufr re B, Haymond MW 1987 Use of reciprocal pool specific activities to model leucine metabolism in humans. Am J Physiol 249:E646-E650

25. Motil KJ, Bier DM, Matthews DE, Burke JF, Young VR 1981 Whole body leucine and lysine metabolism studied with $\left[1-{ }^{13} \mathrm{C}\right]$ leucine and $\left[\alpha-{ }^{15} \mathrm{~N}\right] l y s i n e:$ response in healthy young men given excess energy intake. Metabolism 30:783-791

26. Biolo G, Tessari P, Inchiostro S, Bruttomesso D, Fongher C, Sabadin L, Fratton M, Valerio A, Tiengo A 1992 Leucine and phenylalanine kinetics during mixed meal ingestion: a multiple tracer approach. Am J Physio 262:E455-E463

27. Beaufrère B, Fournier V, Salle B, Putet G 1992 Leucine kinetics in fed low-birth-weight infants: importance of splanchnic tissues. Am J Physiol 263:E214-E220

28. Beaufrère B, Horber FF, Schwenk WF, Marsh HM, Matthews D, Gerich JE, Haymond MW 1989 Glucocorticosteroids increase leucine oxidation and impair leucine balance in humans. Am J Physiol 257:E712-E721

29. Matthews DE, Marano MA, Campbell RG 1993 Splanchnic bed utilization of leucine and phenylalanine in humans. Am J Physiol 264:E109-E118

30. Maiz A, Sobrado J, Moldawer LL, Blackburn GL, Bistrian BR 1984 Protein dynamics during refeeding of protein-depleted rats: effects of increasing amino acid intake by TPN or enteral continuous feeding. J Nutr 114:75-88

31. Hughes CA, Dowling RH 1980 Speed of onset of adaptative mucosal hypoplasia and hypofunction in the intestine of parenterally fed rats. Clin Sci 59:317-327

32. Levine GM, Deren JJ, Steiger E, Zinno R 1974 Role of oral intake in maintenance of gut mass and dissaccharidase activity. Gastroenterology 67:975-982

33. Yu Y, Burke J, Vogt J, Chambers L, Young V 1992 Splanchnic and whole body $\mathrm{L}-\left[1-{ }^{13} \mathrm{C},{ }^{15} \mathrm{~N}\right]$ leucine kinetics in relation to enteral and parenteral amino acid supply. Am J Physiol 262:E687-E694

34. Schwenk FW, Haymond MW 1987 Effects of leucine, isoleucine, or threonine infusion on leucine metabolism in humans. Am J Physiol 253:E428-E434

35. Goulet O, DePotter S, Salas J, Robert JJ, Rongier M, Hariz MB, Koziet J, Desjeux JF, Ricour C, Darmaun D 1993 Leucine metabolism at graded amino acid intakes in children receiving parenteral nutrition. Am J Physiol 265:E540-E546

36. Morrison WL, Bouchier IAD, Gibson JNA, Rennie MJ 1990 Skeletal muscle and whole-body protein turnover in cirrhosis. Clin Sci 78:613-619

37. Rigo J, Senterre J 1987 Significance of plasma amino acid pattern in preterm infants. Biol Neonate 52(suppl 1):41-49

38. Berganovic N, De Leeuw R, De Vries IJ, Schutgens R 1983 Amino acids in parenteral nutrition of preterm infants: comparison of oral and parenteral supply. Acta Paediatr Scand 72:421-425

39. Heird WC, Dell RB, Helms RA, Greene HL, Ament ME, Karna P, Storm MC 1987 Amino acid mixture designed to maintain normal plasma amino acid patterns in infants and children requiring parenteral nutrition. Pediatrics 80:401-408 